\title{
Profil CT-Scan Non-kontras pada Penderita Nefrolitiasis di Bagian Radiologi FK Unsrat/SMF Radiologi RSUP Prof. Dr. R. D. Kandou Manado periode 1 Januari - 30 Agustus 2016
}

\author{
${ }^{1}$ Aprillia G. C. Pongsapan \\ ${ }^{2}$ Vonny Tubagus \\ ${ }^{3}$ Elvie Loho
}

\author{
${ }^{1}$ Program Studi Pendidikan Dokter Fakultas Kedokteran Universitas Sam Ratulangi Manado \\ ${ }^{2}$ Bagian Radiologi Fakultas Kedokteran Universitas Sam Ratulangi Manado \\ ${ }^{3}$ KSM Bagian Radiologi RSUP Prof. Dr. R. D. Kandou Manado \\ Email: gpongsapan@gmail.com
}

\begin{abstract}
Nephrolitiasis is a disease indicated by the existence of a single or more solid masses of hard material in the kidney tubule, calyx, infundibulum, kidney pelvis, and the whole parts of the kidney. Imaging such as non-contrast CT-Scan is usually used to ascertain the diagnosis of nephrolitiasis. This study was aimed to obtain the profile of non-contrast CTScan of the kidney performed on nephrolithiasis cases at Radiology Division of Medical Faculty University of Sam Ratulangi/Prof. Dr. R. D. Kandou Hospital Manado in the period of January 1 to Agust 30, 2016. This was a descriptive retrospective study using medical records at the Radiology Division. The results showed that there were 63 cases of nephrolitiasis in this study. The highest percentages were in males (71.43\%) and age group of 56-65 tahun $(25.39 \%)$. According to the location, most cases with bilateral nephrolitiasis $(25.39 \%)$. Complication of hydronephrosis was found in $14.29 \%$ of cases. Conclusion: Based on the non-contrast CT-Scan of the kidney, most nephrolithiasis cases were found in males, age group of 46-55 years, bilateral nephrolithiasis, and without complication.
\end{abstract}

Keywords: non-contrast CT-Scan of the kidney, nephrolitiasis

\begin{abstract}
Abstrak: Nefrolitiasis merupakan suatu penyakit dengan gejala ditemukannya satu atau beberapa massa keras yang terdapat di dalam tubuli ginjal, kaliks, infundibulum, pelvis ginjal, serta seluruh bagian ginjal. Pemeriksaan yang sering digunakan dalam penegakan diagnosis nefrolitiasis ialah pemeriksaan imaging, salah satunya CT-Scan. Penelitian ini bertujuan untuk mengetahui profil CT-Scan non-kontras pada penderita nefrolitiasis di Bagian Radiologi Fakultas Kedokteran Universitas Sam Ratulangi/RSUP Prof. Dr. R. D. Kandou Manado periode 1 Januari-30 Agustus 2016. Jenis penelitian ialah deskriptif retrospektif dengan memanfaatkan data rekam medik di Bagian Radiologi RSUP Prof. Dr. R. D. Kandou Manado periode 1 Januari -30 Agustus 2016. Hasil penelitian mendapatkan 63 kasus nefrolitiasis dengan hasil CT-Scan ginjal non-kontras, lebih banyak terjadi pada laki-laki $(71,43 \%)$ dan kelompok usia 46-55 tahun (33,33\%). Berdasarkan letak batu, lebih sering ditemukan letak batu bilateral (36,68\%). Komplikasi hidronefrosis ditemukan pada 14,29\% kasus. Simpulan: Berdasarkan hasil CT-Scan non-kontras pada penderita nefrolitiasis didapatkan nefrolitiasis lebih sering ditemukan pada laki-laki, kelompok usia 46-55 tahun, dengan letak batu bilateral dan tanpa komplikasi.
\end{abstract}

Kata kunci: $C T$-Scan tanpa kontras pada ginjal, nefrolitiasis

Nefrolitiasis merupakan pembentukan deposit mineral kristal pada ginjal. Kristal yang semula hanya bersifat mikroskopik berada di lengkung Henle, tubulus distal 
atau duktus koligen, menjadi semakin membesar dan mudah divisualisasi menggunakan imaging. Nefrolitiasis dapat digolongkan berdasarkan kandungan kalsium, densitas, dan komposisi pembentuk batu. ${ }^{1}$

Angka kejadian nefrolitiasis dalam populasi mencapai $5-12 \%$, dengan puncak kejadian terjadi pada usia 35-55 tahun. Di Amerika Serikat, prevalensi nefrolitiasis meningkat dua kali lipat sejak 1964-1972 dan mulai stabil sejak awal 1980. Peningkatan prevalensi nefrolitiasis meningkat dua kali lipat sejak 1964-1972 dan mulai stabil sejak awal 1980. Peningkatan prevalensi juga terjadi di beberapa negara seperti Jerman, Spanyol dan Italia. Di antara beberapa negara hanya Skotlandia yang mengalami penurunan prevalensi $3.83 \%$ pada tahun 1977 menjadi 3,5\% pada tahun 1987. Di tahun 1980-an dan 1990-an beberapa negara juga melaporkan terjadi peningkatan seperti Thailand, Korea, Spayol, Taiwan, dan China. Secara global, rata-rata prevalensi sebesar 3,25\% pada tahun 1980 -an dan $5,64 \%$ pada tahun 1990-an. ${ }^{2}$

Penyakit nefrolitiasis merupakan masalah kesehatan yang cukup bermakna, baik di Indonesia maupun di dunia. Di Indonesia, kasus penyakit nefrolitiasis merupakan penyakit yang relatif tinggi jumlah penderitanya $(0,5 \%$ dari populasi). Data yang dikumpulkan dari rumah sakit di seluruh Indonesia pada tahun 2002 ialah sebesar 37.636 kasus baru dengan jumlah kunjungan sebesar 58.959 orang sedangkan jumlah pasien yang dirawat sebesar 19.018 orang, dengan jumlah kematian sekitar 378 orang. $^{3}$

Nefrolitiasis yang paling sering terbentuk ialah batu kalsium oksalat (80\%). Jenis batu lainnya yang tersering berturut-turut ialah batu asam urat, batu kalsium fosfat, batu sitrat, dan batu sistin. ${ }^{1}$ Di Sulawesi Utara ditemukan sebesar $0,5 \%$. Prevalensi penyakit nefrolitiasis meningkat seiring bertambahnya usia, tertinggi pada kelompok usia 55-64 tahun 1,3\%, menurun sedikit pada kelompok usia 64-74 tahun 1,2\% dan usia kurang lebih 75 tahun 1,1\%. Prevalensi tertinggi pada masyarakat tidak bersekolah dan tidak tamat SD $0,8 \%$. Prevalensi di pedesaan sama tinggi dengan perkotaan $0,6 \% .^{3}$ Pemeriksaan yang sering digunakan dalam penegakan diagnosis nefrolitiasis ialah pemeriksaan imaging, salah satunya ialah CT-Scan. Pemeriksaan CT-Scan memungkinkan untuk menghasilkan gambaran volumetrik (kemampuan membuat potongan tipis secara spiral) sehingga mampu mendeteksi kelainan organ intra abdominals umumnya dan pada saluran kencing secara cross-sectional. Pemeriksaan ini relatif murah dan mudah dilakukan.

Penelitian ini bertujuan untuk mengetahui gambaran CT-Scan non-kontras ginjal pada penderita nefrolitiasis di Bagian Radiologi FK Unsrat/SMF RSUP Prof. Dr. R. D. Kandou Manado periode 1 Januari-30 Agustus 2016.

\section{METODE PENELITIAN}

Penelitian ini dilakukan di Bagian Radiologi Fakultas Kedokteran Universitas Sam Ratulangi/SMF Radiologi RSUP Prof. Dr. R. D Kandou Manado. Jenis penelitian ialah retrospektif menggunakan data rekam medik periode 1 Januari-30 Agustus 2016 dari penderita dengan diagnosis klinis nefrolitiasis dan dilakukan pemeriksaan CT-Scan non-kontras. Data hasil penelitian ditabulasi berdasarkan jenis kelamin, kelompok usia, letak batu, dan komplikasi hidronefrosis.

\section{HASIL PENELITIAN}

Berdasarkan hasil pengumpulan data sekunder yang dilakukan secara retrospektif di SMF Radiologi RSUP Prof. Dr. R. D. Kandou pada penderita nefrolitiasis yang dilakukan pemeriksaan CT-Scan nonkontras selama periode 1 Januari-30 Agustus 2016 didapatkan 63 kasus. Distribusi penderita berdasarkan jenis kelamin didapatkan 18 orang perempuan $(28,57 \%)$ dan 45 orang laki laki $(71,43 \%)$.

Distribusi penderita berdasarkan kelompok usia memperlihatkan bahwa kasus nefrolitiasis terbanyak pada golongan usia 46-55 tahun $(33,33 \%)$, diikuti oleh golongan usia >65 tahun, 56-65 tahun, 36-45 tahun, 
dan yang paling sedikit ialah golongan usia 26-35 tahun $(6,35 \%)$ (Tabel 1).

Tabel 1. Distribusi penderita berdasarkan usia

\begin{tabular}{ccc}
\hline Usia (tahun) & n & \% \\
\hline $26-35$ & 4 & 6,35 \\
$36-45$ & 9 & 14,28 \\
$46-55$ & 21 & 33,33 \\
$56-65$ & 13 & 20,63 \\
$>65$ & 16 & 25,39 \\
Jumlah & 63 & 100 \\
\hline
\end{tabular}

Distribusi penderita berdasarkan letak batu mendapatkan letak batu terbanyak ialah bilateral $(36,68 \%)$ diikuti oleh letak dekstra $(34,92 \%)$ dan sinistra $(25,39 \%)$ (Tabel 2).

Tabel 2. Distribusi penderita berdasarkan letak batu

\begin{tabular}{ccc}
\hline Letak batu & n & \% \\
\hline Dekstra & 22 & 34,92 \\
Bilateral & 25 & 36,68 \\
Sinistra & 16 & 25,39 \\
Jumlah & 63 & $100 \%$ \\
\hline
\end{tabular}

Distribusi penderita berdasarkan komplikasi hidronefrosis memperlihatkan sebagian besar penderita tanpa komplikasi hidronefrosis $(85,71 \%)$ (Tabel 3).

Tabel 3. Distribusi penderita berdasarkan komplikasi hidronefrosis

\begin{tabular}{ccc}
\hline $\begin{array}{c}\text { Komplikasi } \\
\text { hidronefrosis }\end{array}$ & n & $\%$ \\
\hline Ada & 9 & 14,29 \\
Tidak ada & 54 & 85,71 \\
Jumlah & 63 & 100 \\
\hline
\end{tabular}

\section{BAHASAN}

Pada penelitian ini ditemukan sebanyak 63 kasus penderita nefrolitiasis yang dilakukan pemeriksaan CT-Scan nonkontras di Bagian Radiologi FK Unsrat/ SMF Radiologi RSUP Prof. Dr. R. D. Kandou Manado periode 1 Januari - 30 Agustus 2016.

Berdasarkan jenis kelamin didapatkan kasus terbanyak pada laki-laki yaitu 45 orang $(71,43 \%)$ sedangkan pada perempuan
18 orang (28,57\%). Penelitian Alpendri di RS Dr. Sardjito juga menemukan dari 59 penderita batu ginjal, terdapat 32 orang laki laki dan 27 orang perempuan. ${ }^{4}$ hasil penelitian ini sesuai dengan acuan pustaka yang menyatakan bahwa batu ginjal banyak diderita oleh laki laki, dengan angka kejadian 3 kali lebih banyak daripada perempuan. Hal ini disebabkan karena kadar kalsium air kemih sebagai bahan utama pembentuk batu lebih rendah pada perempuan daripada laki-laki, dan kadar sitrat air kemih sebagai bahan penghambat terjadinya batu pada perempuan lebih tinggi daripada laki-laki. ${ }^{5}$ Selain itu, hormon estrogen pada perempuan mampu mencegah agregrasi garam kalsium, sedangkan hormon testosteron yang tinggi pada laki-laki menyebabkan peningkatan oksalat endogen oleh hati yang selanjutnya memudahkan terjadinya kristalisasi. ${ }^{5,6}$

Berdasarkan kelompok usia didapatkan jumlah penderita terbanyak pada kelompok usia 46-55 tahun yaitu 21 orang $(33,33 \%)$, kemudian pada kelompok usia > 65 tahun, yaitu 16 orang $(25,39 \%)$, kelompok usia 56-65 tahun yaitu 13 orang $(20,63 \%)$, kelompok usia 36-45 tahun yaitu 9 orang (14,28\%), dan kelompok usia 26-35 tahun yaitu 4 orang $(6,35 \%)$. Penelitian sebelumnya yang dilakukan oleh Alpendri di RS Dr. Sadjito melaporkan bahwa usia terbanyak yang menderita batu ginjal ialah kelompok usia 40-59 tahun pada laki laki dan kelompok usia 40-59 tahun pada perempuan. ${ }^{4}$ Penelitian ini sejalan dengan acuan pustaka yang menyatakan bahwa penyakit ini umumnya didapatkan pada dekade ketiga sampai kelima. Bertambahnya usia menyebabkan gangguan peredaran darah seperti hipertensi dan kolesterol tinggi. Hipertensi dapat menyebabkan pengapuran ginjal yang dapat berubah menjadi batu, sedangkan kolesterol tinggi merangsang agregasi dengan kristal kalsium oksalat dan kalsium fosfat sehingga mempermudah terbentuknya batu. ${ }^{6}$

Berdasarkan letak batu, dari 63 kasus nefrolitiasis yang mempunyai gambaran CT-Scan non-kontras pada periode 1 Januari-30 Agustus 2016, terdapat 22 orang 
$(34,92 \%)$ dengan nefrolitiasis dekstra, 25 orang $(36,68 \%)$ dengan nefrolitiasis bilateral, dan 16 orang $(25,39 \%)$ dengan nefrolitiasis sinistra. Batu ginjal adalah suatu keadaan di mana terdapat batu di dalam organ ginjal. Jumlah batu tersebut dapat satu atau lebih, dan dapat berada di ginjal kiri, kanan, atau keduanya. ${ }^{7}$

Berdasarkan komplikasi hidronefrosis pada 63 kasus nefrolitiasis yang mempunyai gambaran CT-Scan non kontras periode 1 Januari-30 Agustus 2016, terdapat 9 orang $(14,29 \%)$ dengan komplikasi hidronefrosis dan 54 orang $(85,71 \%)$ tanpa komplikasi hidronefrosis. Hidronefrosis disebabkan oleh stenosis hubungan pielum dan ureter yang disebut stenosis subpelvik. Penyebab lain ialah kelainan motilitas hubungan pelvioureter, yaitu peristaltik dari pielum ke ureter terhambat sehingga terjadi bendungan dan mengakibatkan hidronefrosis. Biasanya kelainan ini ditemukan karena faal ginjal berangsurangsur terganggu atau terjadinya penyulit seperti pembentukan batu (nefrolitiasis), infeksi, hematuria, atau hipertensi. Bendungan berkala dapat menyebabkan kolik. Kolik ginjal ini tanpa hematuria dan teraba pembengkakan ginjal. ${ }^{8}$

\section{SIMPULAN}

Berdasarkan hasil penelitian yang dilakukan di Bagian Radiologi FK Unsrat/ SMF Radiologi RSUP Prof. Dr. R. D. Kandou Manado periode 1 Januari-30 Agustus 2016 dapat disimpulkan bahwa penderita nefrolitiasis lebih banyak pada laki-laki, kelompok usia 46-55 tahun, dengan letak batu bilateral dan tanpa komplikasi hidronefrosis.

\section{SARAN}

Masyarakat sebaiknya lebih memperhatikan pola hidup sehat untuk mencegah terbentuknya batu ginjal, khususnya untuk kelompok yang rentan. Juga penanganannya sebaiknya dilakukan sedini mungkin untuk mencegah terjadinya komplikasi yang lebih parah di kemudian hari.

\section{DAFTAR PUSTAKA}

1. Suharjo JB, Cahyono B. Manajemen batu ginjal. Medical Review. 2010;23(1): 29-35

2. Romero V, Akpinar H, Assimos DG. Kidney stones: a global picture of prevalence, insidence, and associated risk factors. Rev Urol. 2010;12(2/3): e86-96

3. Badan Penelitian dan Pengembangan Kesehatan Kementerian Kesehatan RI. Riset Kesehatan Dasar 2013. Jakarta, 2013

4. Brunner L, Suddarth D. Buku Ajar Keperawatan Medikal Bedah. Jakarta: EGC, 2002.

5. Purnomo BB. Dasar-Dasar Urologi (3rd ed). Jakarta: Perpustakaan Nasional Republik Indonesia, 2003.

6. Tanagho EA, McAninch JW. Smith's General Urology (16th ed). New York: Lange Medical Book, 2004.

7. Menon M, Resnick, Martin I. Urinary lithiasis: Etiology and endourology. In: Chambell's Urology (8th ed). Philadelphia: WB Saunder Company, 2002.

8. Drach GW. Urinary lithiasis. In: Chambell's Urology (5th ed). Philadelphia: WB Saunder Company, 1996. 